\title{
FUNKCJE PREZYDENTA REPUBLIKI LITEWSKIEJ W ŚWIETLE KONSTYTUCJIZ 1992 R.
}

\section{Uwagi wstępne}

Ustrój konstytucyjny Republiki Litewskiej w świetle ustawy zasadniczej z 1992 r. $^{1}$ - nie nawiązuje wprost do żadnego z klasycznych modeli, lecz jest swoistym połączeniem cech systemu parlamentarno-gabinetowego i parlamentarno-prezydenckiego. Szczególną uwagę zwraca pozycja prezydenta, gdyż determinuje ona układ relacji na linii egzekutywa - legislatywa i w rezultacie system rządów. W niniejszym opracowaniu zostanie dokonana analiza zasadniczych funkcji prezydenta w świetle konstytucji z 1992 r. ${ }^{2}$. Egzegeza przepisów konstytucyjnych pozwala na wyróżnienie trzech podstawowych funkcji prezydenta Republiki Litewskiej: funkcji przedstawiciela państwa, funkcji wykonawczej oraz funkcji arbitra. Przemawia za tym analiza przepisów konstytucji określających zakres kompetencji prezydenta, a częściowo również bezpośrednio pełnionych przez niego funkcji. Należy również poczynić wstępną uwagę, że samo wyróżnienie wskazanych funkcji nie oddaje w pełni specyfiki pozycji ustrojowej prezydenta Republiki Litewskiej. Konieczna jest $\mathrm{w}$ tym celu pogłębiona analiza przepisów konstytucji będących podstawą skonstruowania powyższych funkcji.

\section{Funkcja przedstawiciela państwa}

Funkcja przedstawiciela państwa zadeklarowana jest expressis verbis $\mathrm{w}$ art. 77 konstytucji. Zgodnie z tym przepisem prezydent stoi czele państwa ${ }^{3}$ oraz reprezen-

\footnotetext{
1 Lietuvos Respublikos Konstitucija (Lietuvos Respublikos piliečių priimta 1992 m. spalio 25 d. referendume), „Valstybès žinios“ 1992, nr 33-1014 z późn. zm.; polskie tłumaczenie: Konstytucja Republiki Litewskiej, (tł.) H. Wizner, (wstęp) A.B. Zakrzewski, Warszawa 2006.

2 Pojęcie funkcje organu państwowego autor przyjmuje w najogólniejszym znaczeniu, tj. jako podstawowe kierunki jego działalności (por. A. Jamróz, Status konstytucyjny Prezydenta RP w świetle funkcji określonych w art. 126 konstytucji (propozycje wykładni), (w:) S. Bożyk (red.), Aktualne problemy reform konstytucyjnych, Białystok 2013, s. 85).

3 Dosłownie: jest przywódcą państwa (valstybès vadovas).
} 
tuje państwo litewskie. $Z$ przepisu tego wynika również, że prezydent jest ponadpartyjnym organem, stojącym na straży stabilności funkcjonowania państwa ${ }^{4}$. Dlatego też art. 77 stanowi częściową podstawę do konstruowania funkcji arbitra, ale tylko w wymiarze arbitrażu niewładczego, charakterystycznego dla głowy państwa.

Rola reprezentanta państwa, o której mowa wart. 77 konstytucji, wynika immanentnie z pełnienia przez prezydenta funkcji głowy państwa. Prezydent uosabia jedność organizacji państwowej. Dla pełnienia tej funkcji nie ma zasadniczego znaczenia fakt, że prezydent Republiki Litewskiej wybierany jest bezpośrednio przez ogół obywateli ${ }^{5}$. Może na tym tle powstać pytanie o przedstawicielski charakter tego organu. Litewski ustrojodawca daje wyraz tradycyjnemu podejściu, uznającemu, iż głowa państwa ma reprezentować państwo, nie jest zaś - bez względu na tryb elekcji - przedstawicielem suwerena. Prezydent, mimo że jest wybierany w drodze wyborów powszechnych i bezpośrednich, nie może być uważany za reprezentanta narodu. Jest natomiast przedstawicielem państwa w stosunkach wewnętrznych i zewnętrznych. Sposób wyboru prezydenta nie może być natomiast bez znaczenia dla wykładni przepisów konstytucyjnych i ustawowych, na podstawie których prezydent realizuje swoje kompetencje, oraz politycznych uwarunkowań funkcjonowania tego urzędu.

\section{Funkcja wykonawcza}

Z ogółu rozwiązań litewskiej konstytucji wypływa wniosek, że organizacja aparatu państwowego Republiki Litewskiej oparta jest na monteskiuszowskiej zasadzie trójpodziału władz, choć żaden z jej przepisów nie deklaruje expressis verbis poszanowania tej zasady ${ }^{6}$. Najważniejsze znaczenie ma art. 5 konstytucji, zgodnie z którym władzę państwową w Litwie sprawują Seimas, prezydent, rząd i sąd. Miejsce głowy państwa w tym przepisie (między parlamentem a gabinetem) wskazuje, że wolą ustrojodawcy jest zaliczenie prezydenta do organów egzekutywy, tym bardziej że jest on wyposażony w szereg uprawnień pozwalających na kształtowanie polityki państwa, a nie tylko pełnienie funkcji neutralnego moderatora regulującego działanie systemu politycznego państwa?

$4 \quad$ J. Zieliński, Systemy konstytucyjne Łotwy, Estonii i Litwy, Warszawa 2000, s. 41; A. Hollstein, Das staatsorganisatorische Modell der neuen litauischen Verfassung. Ein dritter Weg zwischen präsidialem und parlamentarischem System?, Köln 1999, s. 109.

5 Zob. więcej: K. Prokop, Tryb wyboru prezydenta Republiki Litewskiej, (w:) E. Kużelewska, A.R. Bartnicki (red.), Zachód w globalnej polityce międzynarodowej, Toruń 2009, s. 128 i n.

6 Zob. V.A. Vaičaitis, The Lithuanian Governmental System, (w:) N. Chronowski, T. Drinóczi, T. Takács (red.), Governmental Systems of Central and Eastern European States, Warszawa 2011, s. 437-438; W. Kręcisz, Republika Litewska, (w:) E. Gdulewicz (red.), Ustroje państw współczesnych, t. 2, Lublin 2002, s. 106-107; D. Górecki, Republika Litewska, (w:) W. Brodziński, D. Górecki, K. Skotnicki, T. Szymczak, Wzajemne stosunki między władzą ustawodawczą i wykonawczą (Białoruś, Czechy, Litwa, Rumunia, Słowacja, Węgry), Łódź 1996, s. 78; M. Giżyńska, Sąd Konstytucyjny Republiki Litewskiej, Olsztyn 2009, s. 31.

7 Zob. G. Mesonis, The President of the Republic of Lithuania and the Constitutional Principle of the Separation of Powers, „Jurisprudencija” 2008, nr 9, s. 48-49; por. A. Bakaveckas, V. Valančius, Few Remarks the Model of Exe- 
Funkcja wykonawcza prezydenta znajduje bezpośrednie oparcie w art. 77 ust. 2 zd. drugie in fine konstytucji, zgodnie z którym prezydent wykonuje wszystkie obowiązki nałożone na niego przez konstytucję oraz ustawy. Ponadto należy podkreślić, iż objęcie przez elekta urzędu prezydenta uwarunkowane jest złożeniem przysięgi Narodowi, że będzie wierny konstytucji Republiki Litewskiej oraz będzie sumiennie wykonywać obowiązki i postępować w jednakowo sprawiedliwy sposób wobec wszystkich (art. 82 ust. 1 konstytucji).

Formalnym przejawem sprawowania funkcji wykonawczej jest wydawanie przez prezydenta zarządzeń. Zarządzenia wydane w sprawach określonych przez art. 85 konstytucji wymagają kontrasygnaty. Zarządzenia w sprawie nadania obywatelstwa kontrasygnuje minister spraw wewnętrznych, zarządzenia w sprawie powołania na placówkę dyplomatyczną - minister spraw zagranicznych, zaś zarządzenia w sprawie wprowadzenia stanu wyjątkowego - premier. W innych sprawach (nieobjętych kontrasygnatą) prezydent może wydawać zarządzenia samodzielnie ${ }^{8}$.

Najważniejszym przejawem funkcji wykonawczej litewskiego prezydenta jest udział w określaniu i prowadzeniu polityki państwa9 ${ }^{9}$. Jest to zadanie wykonywane przez ogół organów państwowych, a jego treścią jest wytyczanie celów polityki państwa, ich realizacja oraz przeznaczanie na to odpowiednich środków finansowych (budżetowych). Szczególnie istotna jest rola prezydenta w sferze polityki zagranicznej oraz bezpieczeństwa i obronności państwa. Kluczowe znaczenie ma art. 84 ust. 1 pkt 1 konstytucji, zgodnie z którym prezydent rozstrzyga ważniejsze problemy polityki zagranicznej ${ }^{10}$ i prowadzi ją wraz z rządem. Ponadto prezydent podpisuje umowy międzynarodowe i zwraca się do Seimasu o ich ratyfikację ${ }^{11}$, na wniosek rządu mianuje i odwołuje przedstawicieli dyplomatycznych Republiki Litewskiej w innych państwach i przy organizacjach międzynarodowych, przyjmuje listy uwierzytelniające i odwołujące akredytowanych przy nim przedstawicieli dyplomatycznych innych państw oraz nadaje najwyższe stopnie dyplomatyczne i tytuły specjalne $^{12}$. Sfera polityki zagranicznej ma o tyle specyficzny charakter, że stykają

cutive Authorities of the Republic of Lithuania, “Часопис КиївськогоУніверситету Права" 2014, nr 1, s. 338.

V. Vaičaitis, The Lithuanian Governmental System..., op. cit., s. 460-461.

9 Jak stwierdził J. Zieliński: „Konstytucja zawiera przepisy otwierające głowie państwa możliwość daleko idącego wpływu na kształtowanie wewnętrznej i zagranicznej polityki państwa” (Prezydent Republiki Litewskiej, (w:) J. Osiński (red.), Prezydent w państwach współczesnych. Modernizacja instytucji, Warszawa 2009, s. 374). Ustrojodawca powierza w ten sposób prezydentowi rolę „merytorycznego decydenta”, a nie tylko organu realizującego decyzje parlamentu. M. Grzybowski, Pozycja ustrojowa prezydenta Litwy - tradycje a współczesność, (w:) S. Sulewski, J. Szymanek (red.), Ustrój polityczny państwa: Polska, Europa, świat. Prace ofiarowane Profesorowi Tadeuszowi Mołdawie z okazji siedemdziesięciolecia urodzin, Warszawa 2013, s. 323; por. J. Tauber, Das politische System Litauens, (w:) W. Ismayr (red.), Die politischen Systeme Osteuropas, Opladen 2002, s. 155; V.A. Vaičaitis, Republic of Lithuania, (w:) C. Kortmann, J. Fleuren, W. Voermans (red.), Constitutional Law of 10 EU Member States. The 2004 Enlargement, Deventer - Alphen aan den Rijn 2006, s. VI-25.

11 Art. 84 ust. 1 pkt 2 konstytucji. A. Surówka, Republika Litewska, (w:) P. Sarnecki (red.), Ustrój Unii Europejskiej i ustroje państw członkowskich, Warszawa 2007, s. 252. 
się w jej ramach uprawnienia prezydenta, rządu i parlamentu. Wymaga w związku z tym współpracy i podejmowania działań zmierzających do osiągnięcia konsensusu między organami władzy państwowej ${ }^{13}$.

Równie poważny jest zakres kompetencji prezydenta w obszarze bezpieczeństwa i obronności państwa, choć podejmuje on decyzje na ogół na wniosek rządu lub za zgodą parlamentu. Nie przysługuje jednak prezydentowi funkcja strażnika bezpieczeństwa państwa, albowiem organem stojącym na straży nienaruszalności terytorium Republiki Litewskiej oraz gwarantującym bezpieczeństwo państwa i porządek publiczny jest rząd (art. 94 pkt 1 konstytucji).

Prezydent jest natomiast naczelnym dowódcą sił zbrojnych (art. 140 ust. 2 konstytucji), niemniej z regulacji ustawowej wynika, że może wydawać rozkazy dowódcy wojska jedynie za pośrednictwem ministra obrony narodowej. Prezydent - za zgodą Seimasu - mianuje i zwalnia dowódcę wojska i szefa służby bezpieczeństwa ${ }^{14}$ oraz nadaje najwyższe stopnie wojskowe ${ }^{15}$. Prezydent stoi na czele Rady Obrony Państwa. W jej skład wchodzi premier, przewodniczący Seimasu, minister obrony kraju i dowódca wojska. Rada omawia i koordynuje najważniejsze kwestie obrony $\mathrm{kraju}^{16}$.

W wypadku zbrojnej napaści, zagrażającej suwerenności państwa lub integralności terytorium, prezydent podejmuje decyzję o obronie państwa, ogłasza mobilizację i wprowadza stan wojenny (art. 142 ust. 2 konstytucji) ${ }^{17}$. Decyzje prezydenta podlegają rozpatrzeniu przez Seimas, jeżeli zaś trwa przerwa międzysesyjna, prezydent zwołuje nadzwyczajną sesję parlamentu. Z kolei stan wyjątkowy może być wprowadzony przez prezydenta tylko w czasie przerwy między sesjami parlamentu, $\mathrm{w}$ przypadkach niecierpiących zwłoki, jeżeli w państwie powstaje zagrożenie dla ustroju konstytucyjnego lub spokoju publicznego. Decyzja prezydenta może być uchylona przez Seimas. Prezydent nie może skorzystać z możliwości wprowadzenia stanu wyjątkowego w czasie trwania sesji parlamentu ${ }^{18}$.

\section{Funkcja arbitra}

Funkcja arbitra sprowadza się do uznania stabilizującej roli prezydenta w procesie funkcjonowania organów państwowych. Chodzi przede wszystkim o rozwiązywanie kryzysów politycznych oraz przywracanie normalnego sposobu funk-

13 Zob. również: M. Grzybowski, Pozycja..., op. cit., s. 319-320.

14 Art. 84 pkt 14 konstytucji. Prezydent powołuje dowódcę wojska na wniosek ministra obrony narodowej.

15 Art. 84 pkt 15 konstytucji. Prezydent mianuje na stopień pułkownika (kapitana żeglugi) i generała (admirała).

16 Art. 140 ust. 1 konstytucji. Na temat kompetencji prezydenta w obszarze bezpieczeństwa i obronności państwa zob. więcej: K. Dunaj, Prawne podstawy bezpieczeństwa narodowego Republiki Litewskiej, (w:) P. Stanisz, M. Czuryk, K. Ostaszewski, J. Święcki (red.), Sprawność a legalność działania administracji publicznej w sferze ochrony porządku i bezpieczeństwa publicznego, Lublin 2014, s. 692-693.

17 W razie konieczności obrony ojczyzny lub wypełnienia międzynarodowych zobowiązań państwa litewskiego kompetencją wprowadzenia stanu wojennego dysponuje Seimas.

18 A. Hollstein, Das staatsorganisatorische..., op. cit., s. 111. 
cjonowania organów państwowych. Wynika z tego, że arbitraż głowy państwa nie jest realizowany w sposób ciągły, ale pojawia się a casu ad casum w sytuacji kryzysu, którego znamiona mogą być usunięte w wyniku interwencji prezydenta podjętej w celu przywrócenia naruszonej równowagi. Pamiętając o różnych możliwych znaczeniach prezydenckiego arbitrażu, autor niniejszych rozważań przyjmuje koncepcję, zakładającą zaangażowanie prezydenta w relacje między rządem a parlamentem, w celu rozwiązania powstałego kryzysu na wypadek zawodności innych czynników systemu politycznego. Interwencja głowy państwa ma przynieść ustabilizowanie systemu rządów i przywrócenie jego efektywności ${ }^{19}$. Funkcja arbitrażowa prezydenta Republiki Litewskiej dekodowana jest z szeregu przepisów konstytucyjnych, żaden jednak z nich nie formułuje jej w sposób bezpośredni ${ }^{20}$.

Najważniejszym przejawem sprawowania funkcji arbitra przez prezydenta Republiki Litewskiej jest możliwość rozwiązania Seimasu w sytuacji kryzysu gabinetowego. Prezydent może rozwiązać izbę w trzech przypadkach: jeżeli w ciągu $30 \mathrm{dni}$ nie podejmie ona uchwały w sprawie programu działania rządu, jeżeli w ciągu 60 dni dwukrotnie nie zaakceptuje programu przedstawionego mu przez rząd oraz jeżeli uchwali rządowi wotum nieufności - wówczas rozwiązanie następuje na wniosek rządu $^{21}$. Prezydent nie może rozwiązać Seimasu w ciągu ostatnich sześciu miesięcy swojej kadencji oraz w terminie sześciu miesięcy od rozpoczęcia kadencji Seimasu wybranego w wyborach przedterminowych.

Litewska konstytucja nie zna instytucji konstruktywnego wotum nieufności. Dlatego też prezydent - działając na wniosek rządu - może skrócić kadencję Seimasu nawet $\mathrm{w}$ razie powstania większości potencjalnie zdolnej do powołania nowego gabinetu. Jest to bardzo groźna broń w rękach egzekutywy, która wymaga zgodnego współdziałania obu jej organów. Może stać się skutecznym środkiem przeciwko próbie obalenia gabinetu cieszącego się zaufaniem głowy państwa (gabinetu prezydenckiego). W ten sposób może dojść do zachwiania pozycji Seimasu, a egzekutywa - przez nowe wybory parlamentarne - może poszukiwać większości gotowej do poparcia jej racji. Niemniej w razie porażki i powstania odpowiedniej większości nieprzychylnej prezydentowi, Seimas wybrany w przedterminowych wyborach może doprowadzić do jego odwołania ${ }^{22}$. Jak widać polityczne ryzyko, jakie podejmuje prezydent decydując się na rozwiązanie Seimasu, jest duże.

19 Zob. więcej: J. Szymanek, Arbitraż polityczny głowy państwa, Warszawa 2009, s. 7-12; B. Dziemidok-Olszewska, Instytucja prezydenta w państwach Europy Środkowo-Wschodniej, Lublin 2003, s. 140-143.

20 Nie jest to więc arbitraż à la française, gdyż konstytucja z 1958 r. daje wyraźną jego podstawę w art. 5. Zgodnie z tym przepisem prezydent $\vee$ Republiki przez swój arbitraż zapewnia prawidłowe funkcjonowanie władz publicznych, jak również ciągłość państwa. Zob. więcej: E. Popławska, Instytucja prezydenta w systemie politycznym $V$ Republiki Francuskiej, Warszawa 1995, s. 43 i n.; J. Szymanek, Arbitraż..., op. cit., s. 157-165.

21 Za równoznaczne z uchwaleniem wotum nieufności uważa się odrzucenie przez Seimas projekt ustawy budżetowej. J. Zieliński, Rząd Republiki Litewskiej, (w:) E. Zieliński, J. Zieliński, Rządy w państwach Europy, t. 3, Warszawa 2006, s. 147; V.A. Vaičaitis, Republic..., op. cit., s. VI-35.

Odpowiedzią Seimasu na akt rozwiązania przez prezydenta może być - rzadko spotykana w innych państwach - możliwość jego obalenia przed upływem pięcioletniej kadencji, co należy uznać za formę politycznej odpowiedzialności głowy państwa (art. 87 konstytucji). 
Ważnym przejawem sprawowania politycznego arbitrażu jest weto ustawodawcze prezydenta pozwalające mu na udział w procesie ustawodawczym. Zgodnie $z$ art. 70 konstytucji prezydent podpisuje ustawy lub stosuje wobec nich weto ${ }^{23}$. Prezydent nie może zawetować ustawy ponownie uchwalonej przez Seimas, ani też przyjętej w drodze referendum. Prezydent w ciągu dziesięciu dni od otrzymania ustawy podpisuje i zarządza jej urzędową publikację albo wraz z umotywowanym wnioskiem zwraca Seimasowi do ponownego rozpatrzenia (art. 71 ust. 1 konstytucji). Jeżeli w przewidzianym terminie prezydent nie zwróci lub nie podpisze ustawy uchwalonej przez Seimas, ustawa ta zaczyna obowiązywać po jej podpisaniu i urzędowym opublikowaniu przez przewodniczącego parlamentu (art. 71 ust. 2). Dokonuje on promulgacji ustawy terminie trzech dni. Jeżeli prezydent, w ciągu dziesięciu dni od otrzymania ustawy, zastosuje wobec niej weto (względnie zgłosi poprawki lub uzupełnienia) ${ }^{24}$, Seimas może ponownie rozpatrzyć i uchwalić ustawę (art. 72 ust. 1). Ponownie rozpatrywaną przez Seimas ustawę uważa się za uchwaloną, jeżeli zostały przyjęte poprawki lub uzupełnienia proponowane przez prezydenta, albo jeżeli głosowało za nią więcej niż 1/2, a w wypadku ustawy konstytucyjnej nie mniej niż 3/5 ogólnej liczby deputowanych (art. 72 ust. 2). Prezydent jest obowiązany do podpisania takiej ustawy nie później niż w ciągu trzech dni i jej niezwłocznego urzędowego opublikowania (art. 72 ust. 3).

W przypadku Republiki Litewskiej za przejaw arbitrażu politycznego prezydenta należy uznać również jego rolę w powołaniu nowego rządu. Nie jest to w żadnym razie udział li tylko formalny, jak w klasycznym systemie parlamentarno-gabinetowym. Dysponując mandatem udzielonym mu przez Naród w wyborach powszechnych i bezpośrednich prezydent może aktywnie włączyć się w proces wyłonienia szefa nowego rządu. Jednakże zgodnie z duchem parlamentarnego systemu rządów należy oczekiwać, że prezydent powoła gabinet cieszący się zaufaniem $\mathrm{Seimasu}^{25}$. Dlatego może on odmówić powołania kandydata reprezentującego większość parlamentarną jedynie w określonych przypadkach ${ }^{26}$. Niemniej nawet w takim przypadku stanowisko większości parlamentarnej może zmusić prezydenta do ustępstw $^{27}$.

Powyżej opisany stan stosunków między prezydentem a rządem i parlamentem wykształcił dopiero kilka lat po wejściu w życie konstytucji z 1992 r. Pierwotnie

Na temat pojęcia ustawy w litewskim prawie konstytucyjnym zob. M. Giżyńska, Procedura legislacyjna w Republice Litewskiej, „Studia Prawnoustrojowe” 2009, t. 9, s. 110-112.

24 Możliwość zgłoszenia przez prezydenta poprawek do ustawy skłania do wniosku, że jego uprawnienie zbliżone jest do roli, którą w innych państwach spełnia izba druga parlamentu. D. Górecki, Republika..., op. cit., s. 96; T. Godlewski, Udział prezydenta Republiki Litewskiej w ustawodawstwie, „Przegląd Prawa Konstytucyjnego” 2014, nr 3, s. 30

25 G. Mesonis, The President..., op. cit., s. 50.

26 Zob. V.A. Vaičaitis, Republic..., op. cit., s. VI-25 i VI-26.

27 Niemniej w 2012 r. prezydent Dalia Grybauskaitè zmuszona była powołać gabinet z udziałem Partii Pracy i jej lidera, na którym ciążyły zarzuty oszustw podatkowych. Zob. D. Auers, Comparative Politics and Government of the Baltic States: Estonia, Latvia and Lithuania in the 21st Century, Basingstoke 2015, s. 51. 
bowiem litewski system rządów wykazywał tendencję ku jego prezydencjalizacji, cechującej się politycznym uzależnieniem gabinetu nie tylko od Seimasu, ale również i prezydenta. Niemniej w 1998 r. Sąd Konstytucyjny, rozstrzygając spór między ówczesnym prezydentem Valdasem Adamkusem a premierem Gediminasem Vagnoriusem orzekł, że po wyborze nowego prezydenta gabinet nie musi składać dymisji, o ile tylko Seimas odnowił mu wotum zaufania ${ }^{28}$.

Możliwości działania prezydenta Republiki Litewskiej w ramach funkcji arbitra jest znacznie ograniczona przez brak możliwości zarządzenia referendum. Dlatego też suweren w drodze głosowania nie może podejmować na wniosek głowy państwa decyzji istotnych dla określenia kierunków polityki państwa ani rozstrzygać ewentualnych sporów między egzekutywą a legislatywą, co negatywnie wpływa na pełnienie przez prezydenta funkcji arbitra. Tylko Seimas, uchwalając odpowiednią ustawę, może przedłożyć narodowi określoną sprawę do rozpatrzenia. Jednakże w procedurze ustawodawczej bierze udział również prezydent. Dysponując wetem zawieszającym ma potencjalny instrument do blokowania inicjatyw parlamentu w przedmiocie zarządzenia referendum ${ }^{29}$.

\section{Podsumowanie}

Analiza funkcji prezydenta Republiki Litewskiej wskazuje, że z jednej strony konstytucja z 1992 r. uznaje prezydenta za organ władzy wykonawczej, biorący aktywny udział w życiu politycznym państwa zgodnie z określonymi przez nią uwarunkowaniami, z drugiej zaś - jako głowa państwa - ma on występować w roli bezstronnego arbitra moderującego działanie systemu politycznego ${ }^{30}$. Uprawnienia prezydenta realizowane w ramach funkcji wykonawczej nie są na tyle silne, by mógł on pretendować do miana szefa egzekutywy. Może on jednak wywierać znaczący wpływ na politykę prowadzoną przez rząd z racji na legitymizację swojej władzy wywodzącą się bezpośrednio z woli suwerena oraz uprawnień arbitrażowych (zwłaszcza możliwości rozwiązania Seimasu lub stosowania weta ustawodawczego).

Jak wynika z powyższej analizy, pełniąc funkcję przedstawiciela państwa, funkcję wykonawczą i funkcję arbitra Prezydent Republiki Litewskiej może korzystać $\mathrm{z}$ istotnego katalogu uprawnień, które - obok elekcji w drodze wyborów powszechnych i bezpośrednich - decydują o jego silnej pozycji ustrojowej, równoważoną wszelako przez Seimas. Rola parlamentu jest na tyle znacząca, że umożliwia ograniczenie swobody działania prezydenta.

\footnotetext{
28 V.A. Vaičaitis, Republic..., op. cit., s. VI-13. Tekst orzeczenia Sądu Konstytucyjnego jest dostępny na stronie internetowej: http://www.Irkt.It/en/court-acts/search/170/ta1119 (data dostępu: 5 lutego 2016 r.).

29 Należy dodać, że prezydentowi przysługuje również prawo inicjatywy ustawodawczej (art. 68 ust. 1). Teoretycznie więc może on doprowadzić do zarządzenia referendum, ale warunkiem sine qua non jest zgoda większości parlamentarnej.

Por. A. Bakaveckas, V. Valančius, Few Remarks..., op. cit., s. 339; T. Godlewski, Udział..., op. cit., s. 37.
} 


\section{BIBLIOGRAFIA}

Auers Daunis. 2015. Comparative Politics and Government of the Baltic States: Estonia, Latvia and Lithuania in the 21st Century. Basingstoke: Palgrave Macmillan.

Bakaveckas. A., Valančius V. 2014. "Few Remarks the Model of Executive Authorities of the Republic of Lithuania”. Часопис Київського Університету Права (1): 338-342.

Dunaj Katarzyna. 2014. Prawne podstawy bezpieczeństwa narodowego Republiki Litewskiej. W Sprawność a legalność działania administracji publicznej w sferze ochrony porządku i bezpieczeństwa publicznego, 685-701. Wydawnictwo Katolickiego Uniwersytetu Lubelskiego.

Dziemidok-Olszewska Bożena. 2003. Instytucja prezydenta w państwach Europy Środkowo-Wschodniej. Lublin: Wydawnictwo Uniwersytetu Marii Curie-Skłodowskiej.

Giżyńska Monika. 2009. „Procedura legislacyjna w Republice Litewskiej”. Studia Prawnoustrojowe (9): 109-122.

Giżyńska Monika. 2009. Sąd Konstytucyjny Republiki Litewskiej. Wydawnictwo Uniwersytetu Warmińsko-Mazurskiego w Olsztynie.

Godlewski Tomasz. 2014. „Udział prezydenta Republiki Litewskiej w ustawodawstwie”. Przegląd Prawa Konstytucyjnego (3): 19-40.

Górecki Dariusz. 1996. Republika Litewska. W Wzajemne stosunki między władzą ustawodawczą i wykonawczą (Białoruś, Czechy, Litwa, Rumunia, Słowacja, Węgry), 76-101. Wydawnictwo Uniwersytetu Lódzkiego.

Grzybowski Marian. 2013. Pozycja ustrojowa prezydenta Litwy - tradycje a współczesność. W Ustrój polityczny państwa: Polska, Europa, świat. Prace ofiarowane Profesorowi Tadeuszowi Mołdawie z okazji siedemdziesięciolecia urodzin, 307-325. Warszawa: Wydawnictwo Sejmowe.

Hollstein Andreas.1999. Das staatsorganisatorische Modell der neuen litauischen Verfassung. Ein dritter Weg zwischen präsidialem und parlamentarischem System? Köln: Verlag Wissenschaft und Politik.

Jamróz Adam. 2013. Status konstytucyjny Prezydenta RP w świetle funkcji określonych w art. 126 konstytucji (propozycje wykładni). W Aktualne problemy reform konstytucyjnych, 77-103. Białystok: Temida 2.

Kręcisz Wojciech. 2002. Republika Litewska. W Ustroje państw współczesnych, t. 2, 99-134. Lublin: Wydawnictwo Uniwersytetu Marii Curie-Skłodowskiej

Mesonis Gediminas. 2008. "The President of the Republic of Lithuania and the Constitutional Principle of the Separation of Powers". Jurisprudencija 9 (111): 46-53.

Popławska Ewa. 1995. Instytucja prezydenta w systemie politycznym V Republiki Francuskiej. Warszawa: Wydawnictwo Sejmowe.

Prokop Krzysztof. 2009. Tryb wyboru prezydenta Republiki Litewskiej. W Zachód w globalnej polityce międzynarodowej, 128-142. Toruń: Wydawnictwo Adam Marszałek.

Surówka Anna. 2007. Republika Litewska. W Ustrój Unii Europejskiej i ustroje państw członkowskich, 241-256. Warszawa: Wolters Kluwer.

Szymanek Jarosław. 2009. Arbitraż polityczny głowy państwa. Warszawa: Dom Wydawniczy „Elipsa”. 
Funkcje Prezydenta Republiki Litewskiej w świetle Konstytucji z 1992 r.

Tauber Joachim. 2002. Das politische System Litauens. W Die politischen Systeme Osteuropas, 149184. Opladen: Leske+Budrich.

Vaičaitis Vaidotas A. 2006. Republic of Lithuania. W Constitutional Law of 10 EU Member States. The 2004 Enlargement, VI-1-VI-68. Deventer - Alphen aan den Rijn: Wolters Kluwer.

Vaičaitis Vaidotas A. 2011. The Lithuanian Governmental System. W Governmental Systems of Central and Eastern European States, 430-483. Warszawa: Wolters Kluwer.

Zieliński Jacek. 2000. Systemy konstytucyjne Łotwy, Estonii i Litwy. Warszawa: Wydawnictwo Sejmowe.

Zieliński Jacek. 2006. Rząd Republiki Litewskiej. W Rządy w państwach Europy, t. 3, 119-165. Warszawa: Oficyna Wydawnicza ASPRA-JR.

Zieliński Jacek. 2009. Prezydent Republiki Litewskiej. W Prezydent w państwach współczesnych. Modernizacja instytucji, 357-400. Warszawa: Szkoła Główna Handlowa w Warszawie. 
The article is devoted to analysis of the constitutional functions of the president of the Republic of Lithuania. According to the author it is possible - in the light of the Constitution of 1992 - to define three functions of the president: state representation, an executive function, and an arbitration function. The function of state representation is directly connected with the president's role as head of state. The executive function means the president is part of the executive power and may participate in the determination of state policy, especially in the sphere of foreign policy and national security. As an arbitrator, the president can stabilize the functioning of Lithuania's political system. The strong position of the president is, however, balanced by the Seimas (Parliament).

Keywords: president of the Republic of Lithuania, functions of the head of State, Constitution of the Republic of Lithuania, arbitration, Seimas

Słowa kluczowe: prezydent Republiki Litewskiej, funkcje głowy państwa, konstytucja Republiki Litewskiej, arbitraż, Seimas 